\title{
Working
}

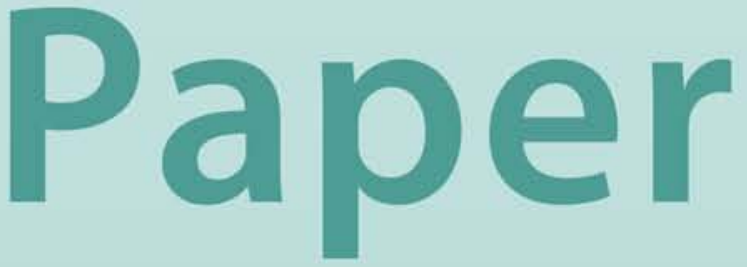


Monetary Policy Transmission Mechanisms in Pacific Island Countries

Yongzheng Yang, Matt Davies, Shengzu Wang, Jonathan Dunn, and Yiqun Wu 


\title{
IMF Working Paper
}

Asia and Pacific Department

\section{Monetary Policy Transmission Mechanisms in Pacific Island Countries}

\section{Prepared by Yongzheng Yang, Matt Davies, Shengzu Wang, Jonathan Dunn, and Yiqun Wu}

Authorized for distribution by Ray Brooks

April 2011

\begin{abstract}
During the global financial crisis, central banks in Pacific island countries eased monetary policy to stimulate economic activity. Judging by the ensuing movements in commercial bank interest rates and private sector credit, monetary policy transmission appears to be weak. This is confirmed by an empirical examination of interest rate pass-through and credit growth. Weak credit demand and underdeveloped financial markets seem to have limited the effectiveness of monetary policy, but the inflexibility of exchange rates and rising real interest rates have also served to frustrate the central banks' efforts despite a supporting fiscal policy. While highlighting the importance of developing domestic financial markets in the long run, this experience also points to the need to coordinate macroeconomic policies and to use all macroeconomic tools available in conducting countercyclical policies, including exchange rate flexibility.
\end{abstract}

JEL Classification Numbers: E4, E5.

Keywords: Pacific island countries, monetary policy transmission, interest rates, pass-through Correspondence author’s E-Mail Address: yyang@imf.org

\section{This Working Paper should not be reported as representing the views of the IMF.} The views expressed in this Working Paper are those of the author(s) and do not necessarily represent those of the IMF or IMF policy. Working Papers describe research in progress by the author(s) and are published to elicit comments and to further debate. 


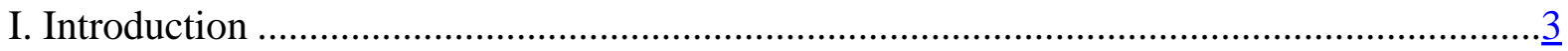

II. Monetary Policy Objectives and Operations............................................................

III. Empirical Evidence on Monetary Pass-Through .........................................................

IV. Constraints on Monetary Policy Transmission..........................................................13

V. Macroeconomic Policy Coordination …...............................................................

VI. Summary and Policy Implications..........................................................................

Tables

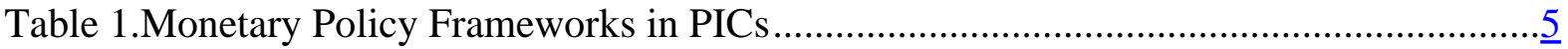

Table 2. Structure of banking sector in PICs 2000-09......................................................14

Figures

Figure 1. Current Account Balance ............................................................................. 4

Figure 2. Consumer Price Inflation (In percentage) .........................................................

Figure 3. Interest Rates and Their Spreads in PICs .......................................................

Figure 4. Long run Interest Rate Pass-through ratio...................................................... $\underline{8}$

Figure 5. Pacific Islands: Private Credit Long-run Pass-through ............................................ $\underline{9}$

Figure 6. Credit and Liquidity Indicators in PICs............................................................. 10

Figure 7. Real Lending Rate (In percentage) .............................................................11

Figure 8. Real Effective Exchange Rates ...................................................................

Figure 9. Nominal Effective Exchange Rates ................................................................

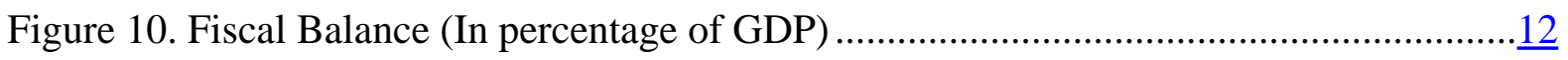

Figure 11. Pacific Islands: Broad Money, 2005-09 Average1 (In percentage of GDP) ..........13

Figure 12. Pacific Islands: Fiscal Balance and Inflation..................................................18

Boxes

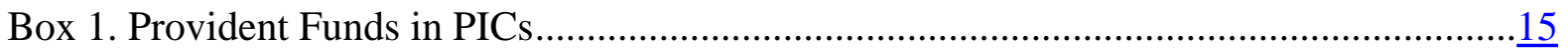




\section{INTRODUCTION ${ }^{1}$}

The recent global financial crisis has tested the effectiveness of monetary policy transmission mechanisms in Pacific island countries (PICs). ${ }^{2}$ At the onset of the crisis, monetary policy remained tight in a number of countries, reflecting the overriding priority of protecting foreign reserves and keeping inflation under control in the wake of the global food and fuel price shocks. However, as the effects of the crisis intensified, central banks began to loosen their policy stance to maintain a flow of credit to productive sectors and ease pressures on existing borrowers, with an explicit objective to lower interest rates. The policy stance was eased through lowering policy rates (Fiji and Samoa), ceasing sale of government and central bank paper into the market (Samoa and Tonga), lowering reserve requirements (Fiji, Tonga, and Vanuatu) and exchange rate devaluation or depreciation (Fiji and Solomon Islands). Despite these efforts, however, there have been limited reductions in bank lending rates and the growth of private credit has been anemic. These sluggish responses have raised a key question about the effectiveness of monetary policy transmission mechanisms in PICs.

PICs are susceptible to external shocks and effective monetary policy is a key tool to maintain macroeconomic stability. As most countries in the region maintain a fixed exchange rate regime, the burden of addressing the impact of exogenous shocks falls most heavily on monetary and fiscal policies. Because of limited capital flows, monetary policy enjoys a certain degree of freedom despite the fixed exchange rate regimes. However, if monetary policy transmission is indeed muted and the prospects for improvement in the short run are limited, effective macroeconomic management will require an appropriate mix of monetary, fiscal and exchange rate policies. In particular, monetary policy should be closely coordinated with fiscal policy to achieve the desired impact. Meanwhile, the fixed exchange rate regimes should not preclude considerations to introduce some flexibility to increase the role of the exchange rate in absorbing external shocks and to provide additional freedom for monetary policy.

The aim of this paper is to provide an assessment of monetary policy transmission mechanisms in PICs and explore options for an appropriate mix of macroeconomic policies. The paper is structured as follows. The next section reviews the key objectives of monetary policy and how it is conducted in PICs. This is followed in Section III by an empirical assessment of monetary policy transmission mechanisms, focusing on the responses of market interest rates and private sector credit growth to policy rates (or their proxies). Section IV examines the structural constraints on monetary policy transmission and identifies areas of reform that could foster financial market development in the long run, and Section $\mathrm{V}$

\footnotetext{
${ }^{1}$ This paper was originally prepared for the $25^{\text {th }}$ Meeting of South Pacific Central Bank Governors in Wellington, New Zealand, 2-3 December 2010. The authors wish to thank the central bank governors and other participants at the meeting for their helpful comments. Ray Brooks, Tubagus Feridhanusetyawan, Tarhan Feyzioglu, Simon Gray, Joji Ide, Papa N'Diaye, Runchana Pongsaparn, and Daranee Saeju provided valuable comments on an earlier version of the paper.

${ }^{2}$ Discussions in this paper cover six PICs that have their own currencies: Fiji, Papua New Guinea (PNG), Solomon Islands, Samoa, Tonga, and Vanuatu.
} 
discusses the role of monetary and fiscal policy coordination as well as of exchange rate flexibility. Section VI concludes with some policy implications.

\section{Monetary Policy ObJectives And Operations}

Monetary policy is primarily aimed at preserving international reserves in the context of fixed exchange rate arrangements in most PICs (Table 1). Countries in the region have small open economies that are subject to frequent internal and external shocks. Maintaining an adequate level of foreign reserves is therefore essential to allow their economies to weather such shocks. A fixed exchange rate provides a nominal anchor, and it is widely believed in the region that exchange rate movements have limited effects on exports, which tend to be dominated by commodities. It should be noted, however, that some industries, such as tourism, do seem to respond strongly to exchange rate movements, as evidenced by Fiji's booming tourism following the 20 percent devaluation of the Fijian dollar in April 2009. There is also a concern that given relatively small foreign exchange markets a move to flexible exchange rates would result in considerable volatility in the currency and domestic prices.

With a narrow export base and the need to import most manufactured goods, food and fuel, trade balances in PICs are generally in deficit. ${ }^{3}$ Although most countries enjoy

Figure 1. Current Account Balance (In percent of GDP) a surplus on the services and income accounts due to tourism and remittances, current account deficits are often very high (Figure 1). Capital inflows-both private and official that are needed to offset the current account deficits-are volatile. Monetary policy therefore needs to be vigilant to contain import demand-speculative capital inflows are not a significant issue in PICs at the

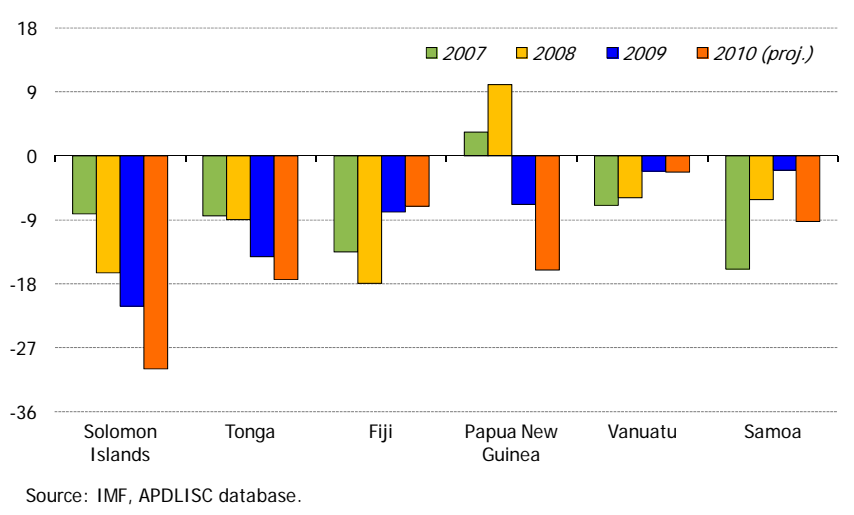
moment, but could become an issue given ample global liquidity.

Maintaining price stability is also a key objective, as is preserving financial sector stability in some countries. While managing aggregate demand is the key focus in maintaining price stability, movements in world commodity prices and domestic supply conditions, mainly in agriculture, often play a dominant role in determining inflation outcomes in PICs. This highlights the importance of monetary policy not only in mitigating the direct impact of exogenous shocks, but also in preventing their second-round effects on inflation with support of other policies (e.g., through restraint on public sector wage bills). Information and analysis of such effects are often lacking, and policy makers therefore have to take decisions based on

${ }^{3}$ PNG is an exception; its exports are dominated by minerals and petroleum. PNG's current account deficit in 2009/10 was driven by large imports of goods and services for the construction of a large liquefied natural gas project. 
judgment and with the knowledge that monetary policy actions to influence domestic demand often have limited impact on headline inflation and their longer-term impact is subject to considerable uncertainty. The role of monetary policy in maintaining financial sector stability is mainly reflected in combating high inflation and non-performing loans by avoiding excessive money and credit expansion. Other policy tools that central banks use to ensure financial sector stability are prudential regulation and supervision. ${ }^{4}$

Table 1.Monetary Policy Frameworks in PICs

\begin{tabular}{|c|c|c|c|c|}
\hline Country & Monetary Objectives & $\begin{array}{l}\text { Monetary } \\
\text { Target }\end{array}$ & $\begin{array}{l}\text { Main Monetary } \\
\text { Instruments }\end{array}$ & $\begin{array}{l}\text { Exchange Rate } \\
\text { Regime }\end{array}$ \\
\hline Fiji & $\begin{array}{l}\text { Promote monetary stability and a } \\
\text { sound financial structure; foster } \\
\text { credit and exchange conditions } \\
\text { conducive to orderly and } \\
\text { balanced economic development. }\end{array}$ & $\begin{array}{l}\text { Broad money } \\
\text { (M2) }\end{array}$ & $\begin{array}{l}\text { OMO; discount } \\
\text { windows; } \\
\text { policy rate }\end{array}$ & $\begin{array}{l}\text { Pegged to a basket } \\
\text { (USD, AUD, Euro, } \\
\text { etc.) }\end{array}$ \\
\hline PNG & $\begin{array}{l}\text { Achieve and maintain price } \\
\text { stability and financial system } \\
\text { stability, and promote macro- } \\
\text { economic stability and economic } \\
\text { growth. }\end{array}$ & $\begin{array}{l}\text { Broad money } \\
\text { (M3) }\end{array}$ & $\begin{array}{l}\text { OMO; discount } \\
\text { windows; } \\
\text { policy rate }\end{array}$ & Float \\
\hline Samoa & $\begin{array}{l}\text { Promote sustainable real } \\
\text { economic growth by maintaining } \\
\text { price stability and international } \\
\text { reserves viability. }\end{array}$ & $\begin{array}{l}\text { Broad money } \\
\text { (M2) }\end{array}$ & $\begin{array}{l}\text { OMO; discount } \\
\text { rate; reserve } \\
\text { requirements; } \\
\text { repos }\end{array}$ & $\begin{array}{l}\text { Pegged to a basket } \\
\text { within a } \pm 2 \text { percent } \\
\text { band (NZL, AUS, US, } \\
\text { Euro) }\end{array}$ \\
\hline $\begin{array}{l}\text { Solomon } \\
\text { Islands }\end{array}$ & $\begin{array}{l}\text { Promote monetary stability and a } \\
\text { sound financial structure; foster } \\
\text { financial conditions conducive to } \\
\text { orderly and balanced } \\
\text { development. }\end{array}$ & $\begin{array}{l}\text { Broad money } \\
\text { (M3) }\end{array}$ & $\begin{array}{l}\text { Liquid asset } \\
\text { requirement; } \\
\text { foreign } \\
\text { exchange } \\
\text { surrender }\end{array}$ & $\begin{array}{l}\text { De facto peg to the US } \\
\text { dollar }\end{array}$ \\
\hline Tonga & $\begin{array}{l}\text { Maintain internal and external } \\
\text { monetary stability; promote a } \\
\text { sound and efficient financial } \\
\text { system; support macroeconomic } \\
\text { stability and economic growth. }\end{array}$ & $\begin{array}{l}\text { Broad money } \\
\text { (M2) }\end{array}$ & $\begin{array}{l}\text { OMO; } \\
\text { statutory } \\
\text { reserve } \\
\text { deposit; credit } \\
\text { ceilings }\end{array}$ & $\begin{array}{l}\text { Pegged to a basket } \\
\text { with monthly } \\
\text { adjustment band of up } \\
\text { to } 5 \text { percent }\end{array}$ \\
\hline Vanuatu & $\begin{array}{l}\text { Maintain low and stable inflation } \\
\text { rate and maintain a sufficient } \\
\text { level of official foreign exchange } \\
\text { reserves. }\end{array}$ & $\begin{array}{l}\text { Broad money } \\
\text { (M2) }\end{array}$ & $\begin{array}{l}\text { Statutory } \\
\text { reserve } \\
\text { deposit; OMO; } \\
\text { rediscount rate }\end{array}$ & $\begin{array}{l}\text { Adjustable peg, linked } \\
\text { to an undisclosed } \\
\text { transactions-weighted } \\
\text { basket }\end{array}$ \\
\hline
\end{tabular}

Source: Authors’ compilation.

Most central banks in the region explicitly include promotion of growth in their monetary policy objectives. Indeed, most do react to threats to growth by loosening monetary policy, as

\footnotetext{
${ }^{4}$ Recent research has highlighted the importance of effective prudential supervision-as well as better regulation-in maintaining financial sector stability. In drawing lessons from the global financial crisis, Viñals and Fletcher (2010) argue that good supervision is "intrusive, skeptical, proactive, comprehensive, adaptive, and conclusive.”
} 
shown during the recent global financial crisis. It is widely recognized that with a small and narrow base of domestic production, the effects of monetary policy on domestic supply are generally weak (tourism is probably an exception), and credit growth often translates largely into raising import demand with limited pass-through into the domestic economy. Thus, the effectiveness of monetary policy in managing domestic supply and aggregate demand is often diminished because of limited capacity of domestic industries and large external leakages.

Like in any other region, it is difficult for PICs to achieve these multiple objectives using monetary policy alone even if its transmission were strong. This difficulty was made abundantly clear during the 2007-08 global food and fuel crisis. To arrest 20 the rapid losses of foreign reserves as a result of rising import costs and to prevent inflation from getting out of control, countries needed to tighten monetary policy. Yet such tightening would have exacerbated falling liquidity in the economy and rising production costs. The limitation of monetary policy was also evident at the onset of the Figure 2. Consumer Price Inflation (In percentage)

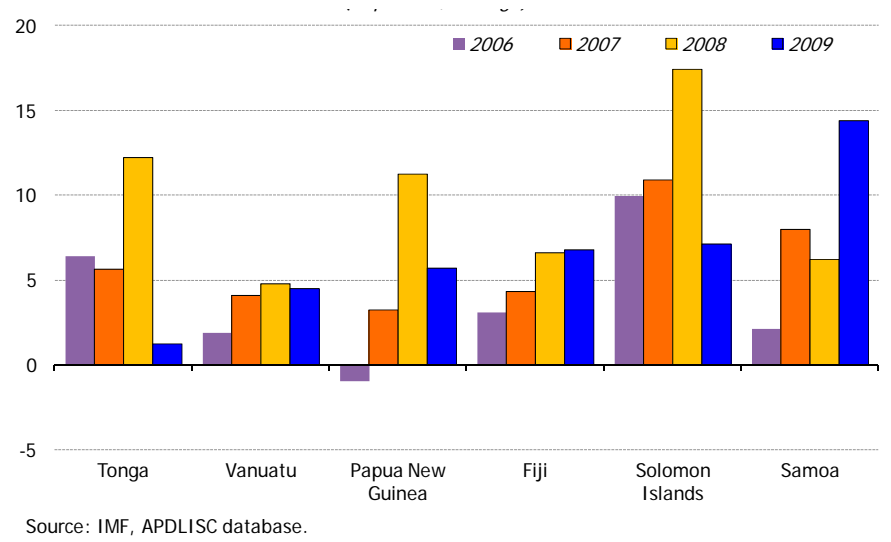
global financial crisis. Despite declining external demand for exports (including tourism) and falling growth, some PICs were reluctant to ease monetary policy as inflation remained high (Figure 2) and international reserves were low. Exchange rate depreciation-which was not considered an option for most countries because of the fixed exchange rate regime-would have helped cushion the demand shock and contain import growth, though it would have had an adverse effect on inflation. ${ }^{5}$ A fiscal expansion-again not a viable option for some countries that entered the crisis with high public debt-would also have exacerbated inflationary pressure, but it could at least be targeted to help segments of society that were most affected by the crisis. The key point here is that in many circumstances monetary policy cannot achieve one objective (e.g., stimulating growth) without possibly undermining others (e.g., controlling inflation and preserving reserves).

All six PICs under examination conduct their monetary policy through various moneytargeting frameworks (Table 1). Central banks in the region typically target some broad money aggregates such as M2, with a view to ensuring adequate credit growth and a healthy level of foreign reserves. Policy instruments for achieving money targets include policy rates, open market operations (OMO), central bank discount windows, reserve requirements, moral suasion, and sometimes administrative measures (e.g., interest rate/spread and credit controls). Countries are making efforts to move away from administrative measures to market-based instruments. A key policy challenge is to make these market-based instruments

\footnotetext{
${ }^{5}$ Nevertheless, Fiji did decide to devalue its currency by 20 percent in April 2009 to arrest declining foreign reserves.
} 
more effective in the broad macroeconomic policy context (an issue discussed in Section IV below).

\section{EMPIRICAL EVIDENCE ON MONETARY PASS-THROUgh}

Interest rate movements have been used as the key indicator to gauge the effectiveness of monetary policy transmission in PICs. As noted earlier, the lack of response of market interest rates to central bank policy changes during the crisis has been a major source of frustration. It had been hoped that changes in central bank policy rates would translate into commensurate movements in commercial banks' lending and deposit rates and the amounts of credit to the private sector would increase, boosting economic activity. Given this background, our assessment of monetary policy transmission begins with the assessment of the role of policy rates.

The pass-through of policy rates to commercial bank interest rates indeed appears to be low and varies across PICs (Figure 3). While in PNG and Vanuatu commercial banks' deposit and lending rates do seem to respond to changes in policy rates, such a response is hardly discernable in Fiji, Solomon Islands, and Tonga. The low response in the latter group of countries is hardly surprising given that their policy rates do not change very often, indicating either an inactive interest rate policy or the presence of some other policy measures that may have been taken as substitutes for interest rate policies. Indeed, in the case of Fiji, for example, the Reserve Bank of Fiji introduced in 2009 administrative measures to push down lending rates by setting an interest rate ceiling at the end-2008 level and imposing an allowable interest rate spread of 4 percent. While interest rate spreads have fallen

somewhat in Fiji and Vanuatu, they have not changed much, or have even increased, in other PICs. It is worth noting that interest rate spreads in PICs are broadly comparable to those observed in Caribbean countries and their recent developments have followed a similar path (PFTAC, 2010). ${ }^{6}$

\footnotetext{
${ }^{6}$ PFTAC (2010) also shows, based on prudential data, that profitability of PIC banks from interest operations does not appear to be out of line with international norms, though overall profitability is higher than comparable regions when all sources of bank income (not just interest) are considered.
} 
Figure 3. Interest Rates and Their Spreads in PICs
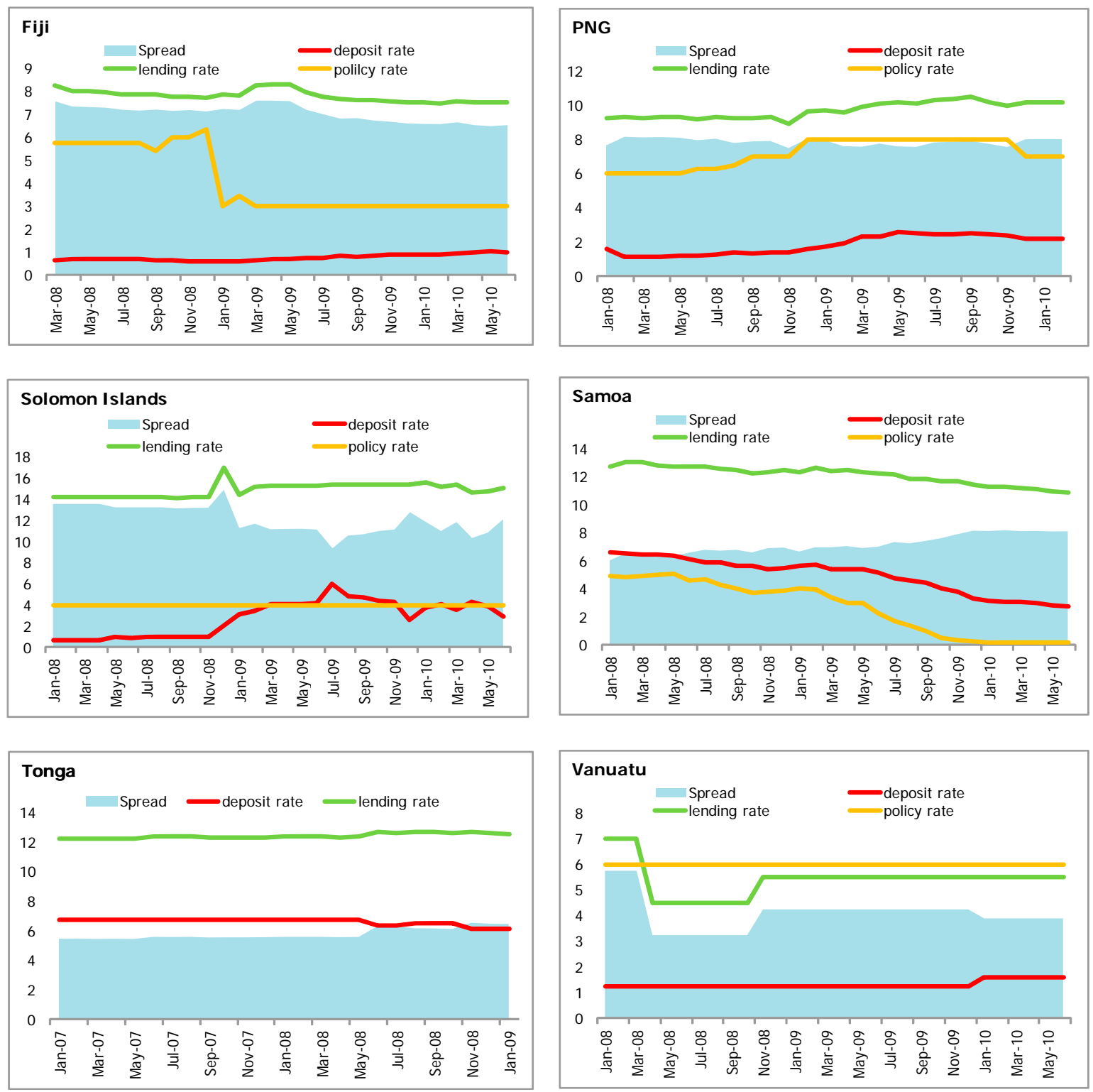

Sources: Country authoroties and IMF staff estimates.

Econometric analysis confirms that interest rate pass-through in PICs is generally low (see the appendix). Based on an Autoregressive Distributed Lags model using monthly data over the period 2001-10, the estimated long-run interest rate pass-through-defined as the percentage point change in commercial banks' lending rates divided by the percentage point change in central bank policy rates-ranges from

Figure 4. Long run Interest Rate Pass-through ratio

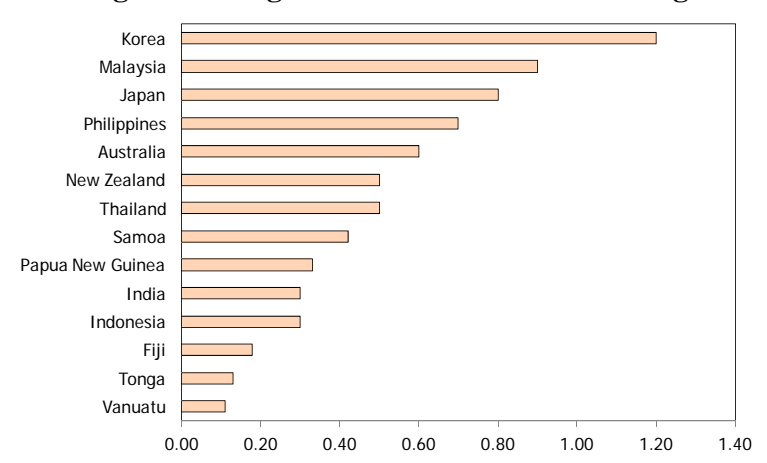


0.1 in Vanuatu to 0.5 in Samoa (Figure 4). ${ }^{7}$ Although it is not surprising that pass-through in PICs is lower than that in other larger Asia-Pacific countries, its absolute levels indeed indicate limited influence of central bank policy rates over commercial bank lending rates in some countries. ${ }^{8}$ The analysis also shows that PNG and Samoa have much higher passthrough than Fiji, Tonga, and Vanuatu. This is primarily because PNG and Samoa's policy rates are more directly linked to money market rates (rates on central bank securities and government paper) and are more actively used to signal the policy stance, as measured by the frequency of change in policy rates (see Figure 3). ${ }^{9}$ This highlights the importance of a well developed money market through which policy rates can directly affect liquidity conditions.

Compared with interest-rate pass-

Figure 5. Pacific Islands: Private Credit Long-run Pass-through through, the response of private sector credit to policy rate changes is more significant. A similar econometric analysis (see the appendix) shows that for each percentage point change in policy rates, the growth of private sector credit responds by a change of 4-5 percentage points in Fiji, PNG and Vanuatu, 11/2 percent in Tonga, and only half a percentage point in Samoa (Figure 5). Such large

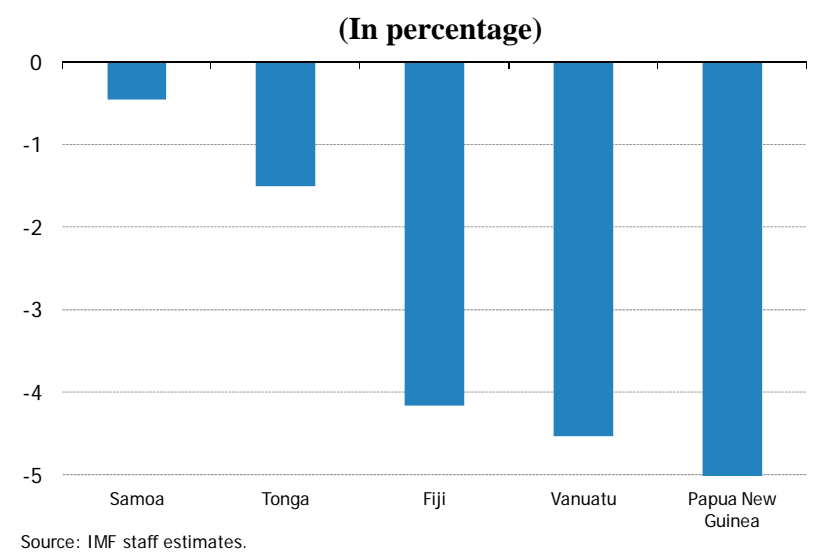
variation of results may reflect different underlying economic circumstances (data could also be an issue). In the case of Samoa, for instance, the limited response of credit growth could be the result of higher interest rate pass-through — competition forces commercial banks to lower lending rates but they are reluctant to increase lending when responding to lower policy rates, perhaps due to limited low-risk lending opportunities. In Fiji and Vanuatu, on the other hand, commercial banks respond by primarily increasing credit rather than lowering lending rates, while banks in PNG seem to respond by both reducing lending rates and increasing credit. In Tonga, both interest rate and credit responses are relatively weak. One possible reason that credit is generally more responsive than lending rates is that banks target risk-adjusted returns on their

\footnotetext{
${ }^{7}$ To the extent that policy rate changes are accompanied by other policy moves (such as changes in reserve requirements), the estimated pass-though would reflect the combined effects of all simultaneous policy changes. This also applies to the estimates of pass-through from policy rates to private sector credit (see next paragraph). For Tonga, the repo rate was used as a proxy for the policy rate. Pass-through rates could not be estimated for Solomon Islands because there are no changes in the policy rate over time.

${ }^{8}$ The results for Fiji here seem to be consistent with the findings of Jayaraman and Choong (2009) that the most effective channel of monetary policy transmission is money supply. The low interest rate pass-through found here is also consistent with findings for developing countries in other regions. Dabla-Norris and Floerkemeier (2006), for instance, show that the interest channel of monetary policy transmission in Armenia is weak.

${ }^{9}$ Given that short-term money market rates are probably more indicative of the monetary policy stance in PICs, it would have been useful to estimate their pass-through to bank lending rates and credit growth. However, data limitations precluded such estimation.
} 
lending. For example, when funding costs are reduced as a result of policy easing, banks may be more willing to extend credit to customers with higher credit risk without lowering interest rates. ${ }^{10}$

Monetary policy transmission appears to have been even weaker during the global crisis than these long-term responses would suggest. Not only has the interest rate pass-through been generally low, but the response of private sector credit appears to have deviated from its long-run behavior. As shown in Figure 6, despite the easing of the policy stance the growth of private sector credit has slowed sharply in the wake of the global financial crisis-in the case of Solomon Islands and Tonga, growth turned negative in 2009. The slow credit growth has also been reflected in the rising levels of excess reserves held by commercial banks and their falling loan-to-deposit ratios in some countries. Nevertheless, the rising level of excess reserves and loan-to-deposit ratios do indicate that monetary policy in PICs has achieved an important objective-ensuring sufficient liquidity when economic activity is weak.

Figure 6. Credit and Liquidity Indicators in PICs
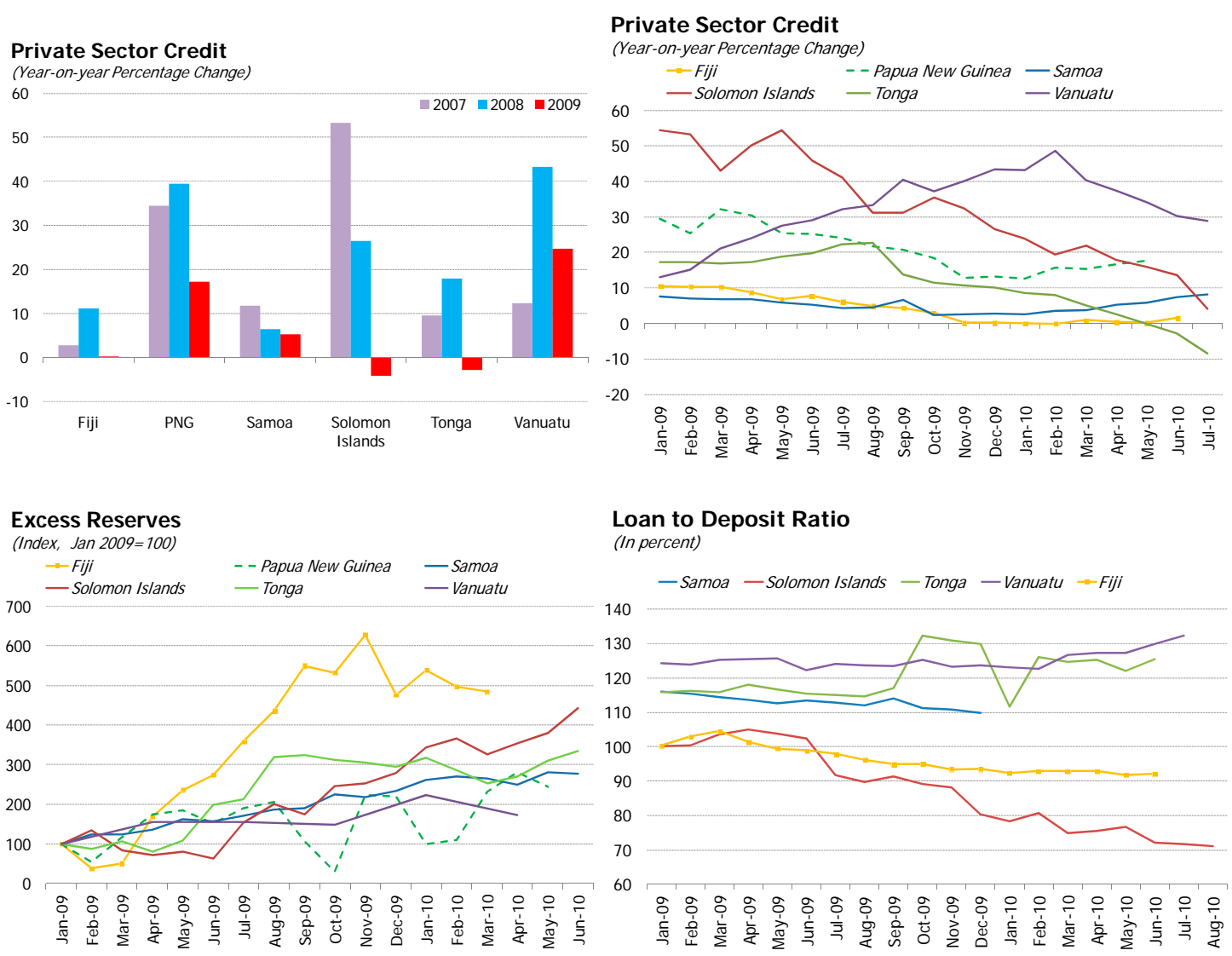

Sources: Country authorities and IMF staff calculations.

The poor interest and credit responses to monetary policy during the crisis seem to reflect the weak state of regional economies as well as the broader international environment. The sharp

${ }^{10}$ An examination of the effective lending rates or distribution of lending rates could shed light on this hypothesis, but data limitations preclude such an analysis at this stage. 
slowdown in economic growth has undoubtedly reduced opportunities for profitable investments. On the supply side, even though central banks have signaled an easing of the monetary policy stance, it appears that commercial banks have been reluctant to lower lending rates or increase lending. This appears to be the case even in Samoa, where longterm interest pass-though is relatively high (Pongsaparn, 2010). The global financial crisis has made banks more risk-averse, resulting in tighter lending standards. This has occurred despite the fact that most banks in the region (mostly owned by Australian parents) have weathered the global financial crisis well. ${ }^{11}$ Other factors have also played a role. In the case of Tonga, the slowdown of credit expansion was a reaction to high non-performing loans arising from a previous lending boom. In Fiji, exchange restrictions and intensified price controls in the wake of the crisis may have dampened the appetite for new investment and hence demand for credit. On the other hand, Vanuatu's strong credit expansion in 2008 and 2009 resulted from the opening of a branch by BRED Bank and ensuing competition in the banking sector.

Developments in real interest rates may have also dampened credit demand during the crisis. As world food and fuel prices began to retreat in the second half of 2008, inflation fell quickly in most PICs, leading to sharp increases in real lending rates and keeping them at elevated levels in most countries (Figure 7). ${ }^{12}$ The sharp fall in Fiji's real lending rates since the second quarter of 2009 reflected the one-off increases of

Figure 7. Real Lending Rate (In percentage)

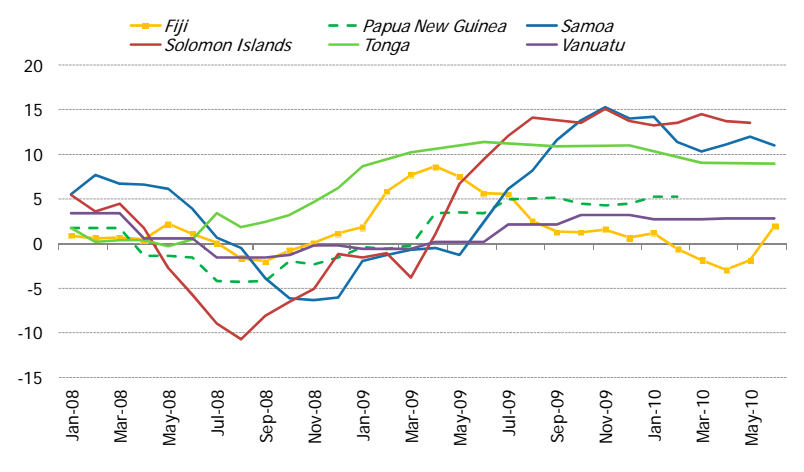
Sources: IMF, IFS databse; and IMF staff calculations. domestic prices in the wake of the April 2009 devaluation. Overall, real borrowing costs for business have increased considerably during the crisis and this has likely contributed to the slow credit growth.

Real exchange rate appreciation during the crisis may have also contributed to weak credit demand. As reported in Table 1 earlier, all PICs except PNG maintain a pegged exchange rate. Although there have been some movements over time, nominal effective exchange rates (NEER) at the end of 2010 for most PICs (with Fiji and Solomon Islands being exceptions) remained roughly at their 2005 levels (Figure 8). Higher inflation than trading partners', largely reflecting the pass-through to domestic markets of higher world food and fuel prices, led to real exchange rate appreciation during the crisis in all six PICs except Fiji. In the case of Solomon Islands the real exchange rate was on an appreciating trend well before world prices began to rise (Figure 9). The decline in world prices since mid-2008 has not brought real exchange rates back to their pre-crisis levels. The monetary easing to boost economic

\footnotetext{
${ }^{11}$ Parent banks in Australia also experienced slower credit growth after the crisis, especially to the corporate sector for similar reasons-tighter credit standards and some corporate deleveraging.

${ }^{12}$ Real lending rates were obtained by deflating nominal rates by the headline consumer price index. Ideally, a core inflation index should have been used, but such data are not available.
} 
activity has therefore not been supported by real exchange rate movements, with Fiji being an exception. Fiji's April 2009 devaluation has led to a sharp real depreciation of the Fiji dollar since the second quarter of 2009, which has boosted tourism amid weak overall economic activity.

Figure 8. Nominal Effective Exchange Rates

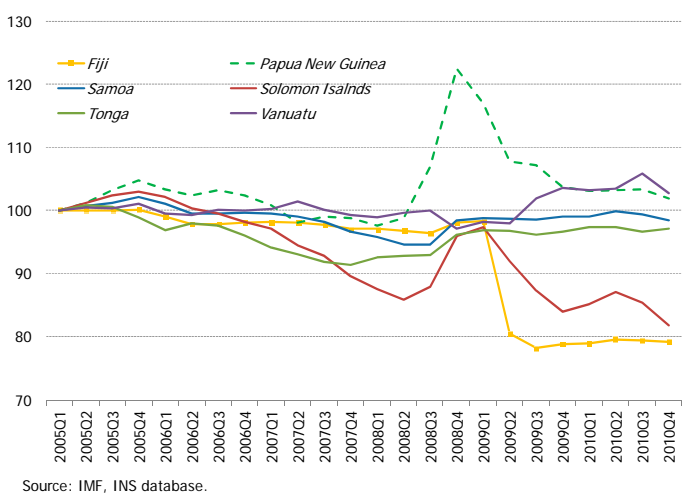

Figure 9. Real Effective Exchange Rates

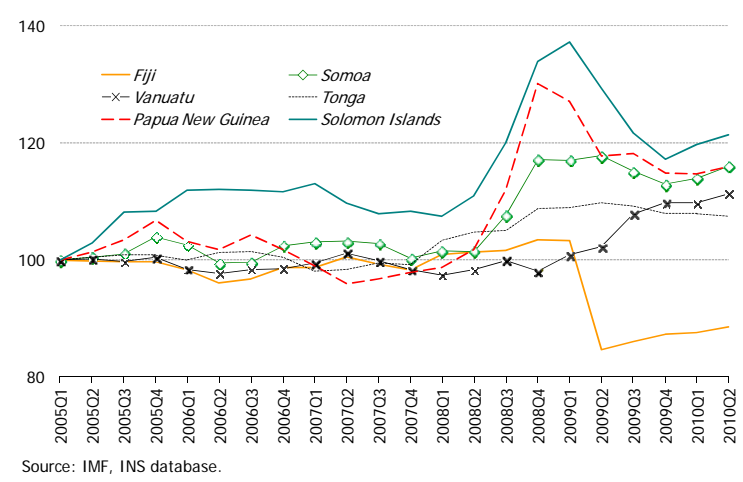

Fiscal policy was eased in most PICs during the crisis to support economic activity. Except Vanuatu (where the policy stance was neutral) and Solomon Islands (where the policy stance was tightened), all other PICs covered here loosened fiscal policy in 2009, and Tonga and Samoa continued to loosen in 2010 (Samoa's policy stance was largely driven by the need for post-Tsunami reconstruction) (Figure 10). At least part of the fiscal expansion has been financed domestically, but given weak private sector activity there was little risk of crowding out and hence the fiscal expansion has most likely not Figure 10 Fiscal Balance (In percentage of GDP) contributed to the slow growth of private sector credit.

Macroeconomic policy developments during the crisis highlight the limitations of monetary policy in economic stabilization without support of other macroeconomic policies. To be sure, the crisis experience does not prove that monetary policy easing has been totally ineffective. One could argue that even though interest and credit responses appear to be weak, the credit situation facing the private sector could have been worse without the policy actions. Nevertheless, the crisis experience does point to the inconsistency between exchange rate and monetary policies, a situation that is difficult to avoid when a fixed exchange rate regime is faced with an adverse terms of trade shock such as rising international prices. 


\section{Constraints on Monetary Policy Transmission}

At the broadest level, the effectiveness of monetary policy transmission depends on the macroeconomic policy framework in which it operates. In particular, since most PICs have a fixed exchange rate regime one way or another, monetary policy is subordinate to the maintenance of the exchange rate regime. However, because of limited capital flows across their borders (at least so far), monetary policy does enjoy a certain degree of autonomy, Namely, higher domestic interest rates in response to monetary policy may not attract rapid capital inflows and bring interest rates back to where they were, thereby largely avoiding increased liquidity and inflation pressures. It is not clear, however, how some private transfers, particularly remittances, respond to domestic interest rates. The literature suggests that remittances respond mainly to the needs of families in migrants' home countries, rather than to returns on investments or exchange rates (Chami et al., 2008). Nevertheless, given the large volumes of remittances received by some PICs (see Australian and New Zealand Governments, 2010), their response to interest rates and exchange rates could make a major difference to the domestic liquidity situation and hence the effectiveness of monetary policy transmission. ${ }^{13}$

The main constraint on monetary policy transmission seems to be Figure 11 Pacific Islands: Broad Money, 2005-09 Average $^{1}$
(In percentage of GDP) underdeveloped domestic financial markets in PICs. Measured by the ratio of broad money (M2) to GDP, domestic money markets are quite shallow, and on average compare unfavorably with Caribbean countries (Figure 11). ${ }^{14}$ Collateralized interbank lending is not widely available, and secondary markets for government and central bank paper are virtually non-existent. Markets for

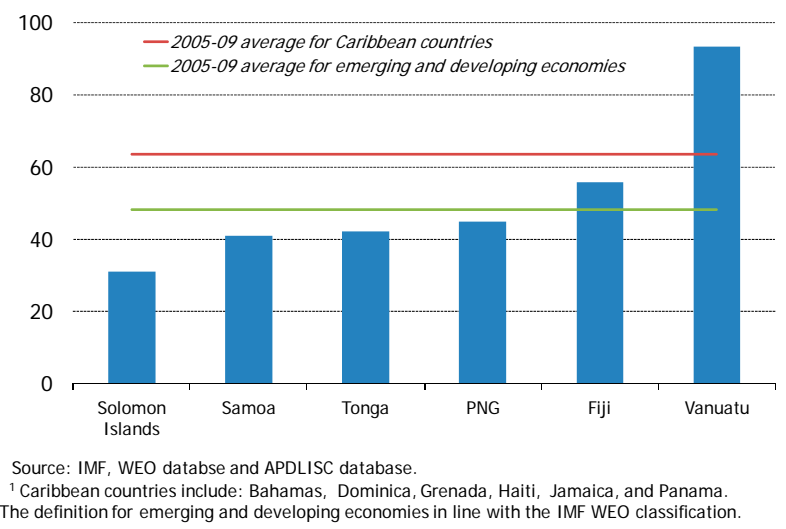
commercial paper, corporate bonds and foreign exchange products are also underdeveloped, while equity markets are still in their infancy. ${ }^{15}$ The underdeveloped state of the financial markets affect not only interest rate and credit pass-through, but also all other channels of monetary policy transmission—namely those through asset prices and exchange rates. ${ }^{16}$

\footnotetext{
${ }^{13}$ This subject may be worth a separate examination.

${ }^{14}$ Of course, in making such comparisons one has to be mindful that despite their smaller population Caribbean countries have high per capita income and are more integrated among themselves and with North American goods and financial markets because of greater geographic proximity.

${ }^{15}$ The lack of foreign exchange products is predictable given the fixed exchange rates in most countries.

${ }^{16}$ For an overview of various channels of monetary policy transmission, see Bank of England (2009) and Loayza and Schmidt-Hebbel (2002).
} 
Lack of vigorous competition in the domestic banking sector may also be partly responsible for the weak monetary policy transmission. Reflecting the small size of domestic markets, there are only a few commercial banks in each of the PICs (Table 2). These banks, together with provident funds and a few insurance companies, are also key players in
Table 2. Structure of banking sector in PICs 2000-09

\begin{tabular}{lccc}
\hline & $\begin{array}{c}\underline{2000} \\
\begin{array}{c}\text { Number of } \\
\text { commercial } \\
\text { banks }\end{array}\end{array}$ & $\begin{array}{c}\underline{\underline{2005}} \\
\text { Number of } \\
\text { commercial } \\
\text { banks }\end{array}$ & $\begin{array}{c}\underline{2009} \\
\text { Number of } \\
\text { commercial } \\
\text { banks }\end{array}$ \\
\hline Solomon Islands & 3 & 3 & 3 \\
Samoa & 3 & 4 & 4 \\
Vanuatu & 4 & 3 & 4 \\
Tonga & 3 & 3 & 3 \\
Papua New Guinea & 6 & 4 & 4 \\
Fiji & 5 & 5 & 5 \\
\hline
\end{tabular}

Sources: Central bank information and IMF staff reports. domestic money and credit markets. Provident funds account for a large share of total domestic financial assets in PICs. Because of the lack of opportunities for long-term investment and restrictions on overseas investment, provident funds often hold large volumes of their assets in bank deposits and government paper. Given their size, actions by provident funds often have a large influence on domestic liquidity and hence of the effectiveness of monetary policy transmission (Box 1).

The development of domestic financial markets will require continued reforms to reduce risk to investors. Broader country risk is perceived to be elevated in PICs, as is economic risk (PFTAC, 2010). Such risks not only find their way into higher interest rates, but also serve as an impediment to the expansion and deepening of financial markets, as investors will require higher returns on their investment. While some of the risk factors (e.g., vulnerability to cyclones) are beyond the governments' control, much can be done to improve market infrastructure for financial development. In many PICs, these would include establishing credit reporting bureaus, secured transactions laws, and collateral registries. Moreover, the enforcement of credit contracts needs to be strengthened to ensure reliable and rapid resolution of defaults, bankruptcies, and disputes.

Policy consistency can also help market development and strengthen signals for monetary policy transmission. Market expectations can play an important role in monetary policy transmission. Central bank independence, policy consistency and effective communications would help build expectations in line with policy intentions. For instance, when fiscal and monetary policies are moving in the same direction, it increases the credibility of monetary policy and the strength of monetary policy transmission. In contrast, if a monetary easing is not supported by the fiscal policy stance, its effect on market interest rates is likely to be muted or to move even in an unintended direction. Similarly, restrictions and controls over interest rates that are inconsistent with market conditions are unlikely to help monetary policy transmission in the long run as market players see greater uncertainty and risk to their future activities. 


\section{Box 1. Provident Funds in PICs}

Provident Funds are the largest financial sector institutions in PICs. They account for the majority of private saving in many PICs. Their assets average around 30 percent of total banking sector assets and reach over 60 percent in Fiji (see chart). Provident fund assets are normally held in a mixture of long-term investments, government paper and bank deposits. Very few funds hold assets overseas, in part due to concerns over the impact that such investment may have on official reserve positions.

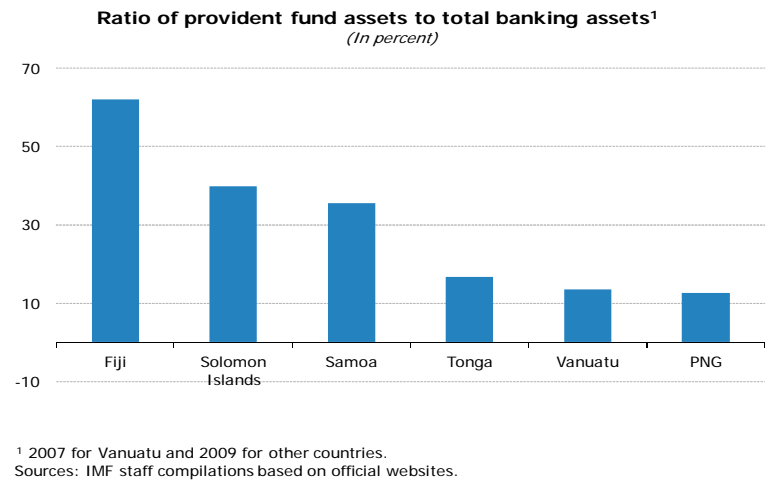

Provident funds complicate the transmission of monetary policy in a number of ways.

- Deposit rates - as provident funds often control much of the liquidity in the banking system banks compete vigorously for their deposits, which are often made available in lumpy amounts. This can drive up banks' cost of funding even when there is ample liquidity in the system, frustrating central bank attempts to ease monetary policy

- $\quad$ Lending rates - provident funds are in some countries significant sources of private sector credit. This can diminish the influence of monetary policy actions on credit growth and aggregate demand as monetary policy actions designed to tighten the credit environment have limited impact on the credit made available by provident funds.

- Dampening price signals - where provident funds are government owned and represent a key source of domestic finance for the budget deficit they can come under pressure to provide finance at lower than true market rates. Some funds also have considerable lending to quasi-government bodies and state-owned enterprises, and such lending is not always on a fully commercial basis.

Some central banks have taken action to moderate the impact of provident funds on the domestic money market. For instance, in Vanuatu the reserve bank placed a temporary ceiling on deposit rates when provident fund offerings began pushing up interest rates as the RBV was trying to loosen policies.

Provident funds are likely to continue to complicate monetary policy transmission in PICs. While markets are still relatively shallow and investment opportunities limited, provident funds are likely to remain one of the main providers of liquidity to the banking system. There are, however, a number of measures that could increase their sensitivity to market interest rates and thus strengthen the transmission of monetary policy. These include ensuring open and transparent price auctions for the deposits they place in the banking system, market-based variable-rate auctions for government securities, increasing the range of financial products available to provident funds for investments and, contingent on the external position, allowing greater levels of investment overseas.

Source: Authors' compilation. 


\section{Macroeconomic Policy Coordination}

The ultimate objective of macroeconomic policies is to achieve high economic growth and low and stable inflation. As noted earlier, it is difficult to rely on a single policy to accomplish this objective, be it fiscal, monetary, or exchange rate policy. Given the relatively weak transmission of monetary policy in PICs, it is particularly important that monetary policy be employed in a macroeconomic policy framework in which all policies are geared toward the same objectives.

Despite the fixed exchange rate regimes adopted in most PICs, exchange rate policy can still play a useful role in economic stabilization. Under a flexible exchange regime, the exchange rate is the first shock absorber of external shocks. Although such an automatic role is precluded under a fixed exchange rate regime, some flexibility of the regime-either through one-off devaluation when facing a negative external shock or through movement within a narrow band - could still have significant stabilizing effects. Fiji, for instance, devalued its dollar by 20 percent in April 2009 when its balance of payments was subject to considerable pressure with foreign reserves running very low. The devaluation helped rebuild reserves quickly, and there have been few second-round effects on inflation. One could argue that had Fiji relied on monetary tightening alone, the domestic price level would have had to fall substantially to restore the external balance, possibly with significant output losses. More generally, Wood (2010) argues that greater downward exchange rate flexibility could be expected to have favorable impacts on competitiveness over the medium to longer run, though it may not be able to counter a recession-induced decline in exports in the short run. Similarly, when a country faces increasing capital inflows, such as experienced in PNG at present as a result of large LNG projects, upward exchange rate flexibility would help reduce inflationary pressure.

The expenditure-switching effects of exchange rate policy can be powerful in PICs. Even though real exchange rate depreciation through devaluations may have limited impact on domestic goods supply, tourism seems to respond well to real exchange rate movements. Moreover, imports (which often consist of a high proportion of manufactured goods) tend to be more elastic, and devaluations can quickly reduce import demand. At the same time, because of high dependency on imports, devaluations can put considerable upward pressure on domestic prices, rendering policymakers reluctant to take such actions. However, an increase in the price of imports is a necessary part of expenditure-switching adjustment, a key reason that the exchange rate can be effective in monetary policy transmission. ${ }^{17} \mathrm{~A}$ critical step in preventing the second-round effects of higher import prices, as Fiji did in 2009, is to have supportive monetary and fiscal policies to stamp out further inflation pressure.

\footnotetext{
${ }^{17}$ Jayaraman and Dahalan (2009) show that in the case of Samoa money (M1) and exchange rate channels are important channels in transmitting monetary impulses to output. In its exchange rate assessment for Fiji, IMF (2010) reports that a one-percent real depreciation leads to a 4 percent increase in gross reserves, This suggests that most of the increase in reserves (excluding the SDR allocation and the repatriation by Fiji National Provident Fund assets) since April 2009 was due to the devaluation.
} 
Fiscal policy plays a particularly important role in maintaining macroeconomic stability in PICs. As discussed earlier, a key objective of monetary policy under most fixed exchange rate regimes in PICs is to protect foreign reserves by keeping inflation in line with that in major trading partners. Such an objective can only be achieved if fiscal policy is prudent and aimed at keeping aggregate demand at an appropriate level. Moreover, when there is a need to stimulate domestic demand — such as when an external shock weakens domestic economic activity-fiscal policy is more powerful under a fixed exchange rate regime. To take advantage of such a role of fiscal policy, countries need to build adequate fiscal space during good times to serve as a policy buffer during bad times.

A prudent fiscal policy can also help ensure adequate credit to the private sector and promote long-term growth and stability. Although it is now less common for governments to borrow directly from central banks (which in turn finance such borrowing by printing money), unless private activity is depressed even a fiscal expansion financed in a non-inflationary manner (e.g., by issuing government paper) will ultimately require a tightening of credit to the private sector to keep overall inflationary pressure under control. This is particularly important in PICs as the public sector tends to be large and government borrowing can have a large crowding-out effect on the private sector, undermining the objective of having private sector-led growth in the region.

At an operational level, fiscal and monetary authorities need to coordinate closely to maintain an appropriate level of liquidity. While central bank operations should aim to maintain money supply at a level consistent with its inflation objective, fiscal authorities should provide central banks with forecasts for their borrowing needs to ensure that adequate liquidity is available. At the same time, there is considerable scope for central banks in the region to strengthen their own monetary projections and liquidity forecasts. Such projections are made challenging by frequent exogenous shocks in the region. In addition, as noted earlier, actions by the large provident funds also have significant effects on domestic liquidity.

Past experience in the region has demonstrated the importance of a prudent fiscal policy in maintaining price stability and promoting growth. Figure 12 shows that smaller fiscal deficits and lower public debt are generally associated with lower inflation among PICs and Caribbean countries. Moreover, countries with lower inflation also seem to experience lower variability of inflation, generating greater certainty for economic agents (as can be seen in Figure 12, smaller bubbles, which indicate lower variability of inflation, tend to be associated with lower levels of inflation). Similarly, both lower fiscal deficits and lower public debt appear to be associated with higher economic growth. 
Figure 8. Pacific Islands: Fiscal Balance and Inflation

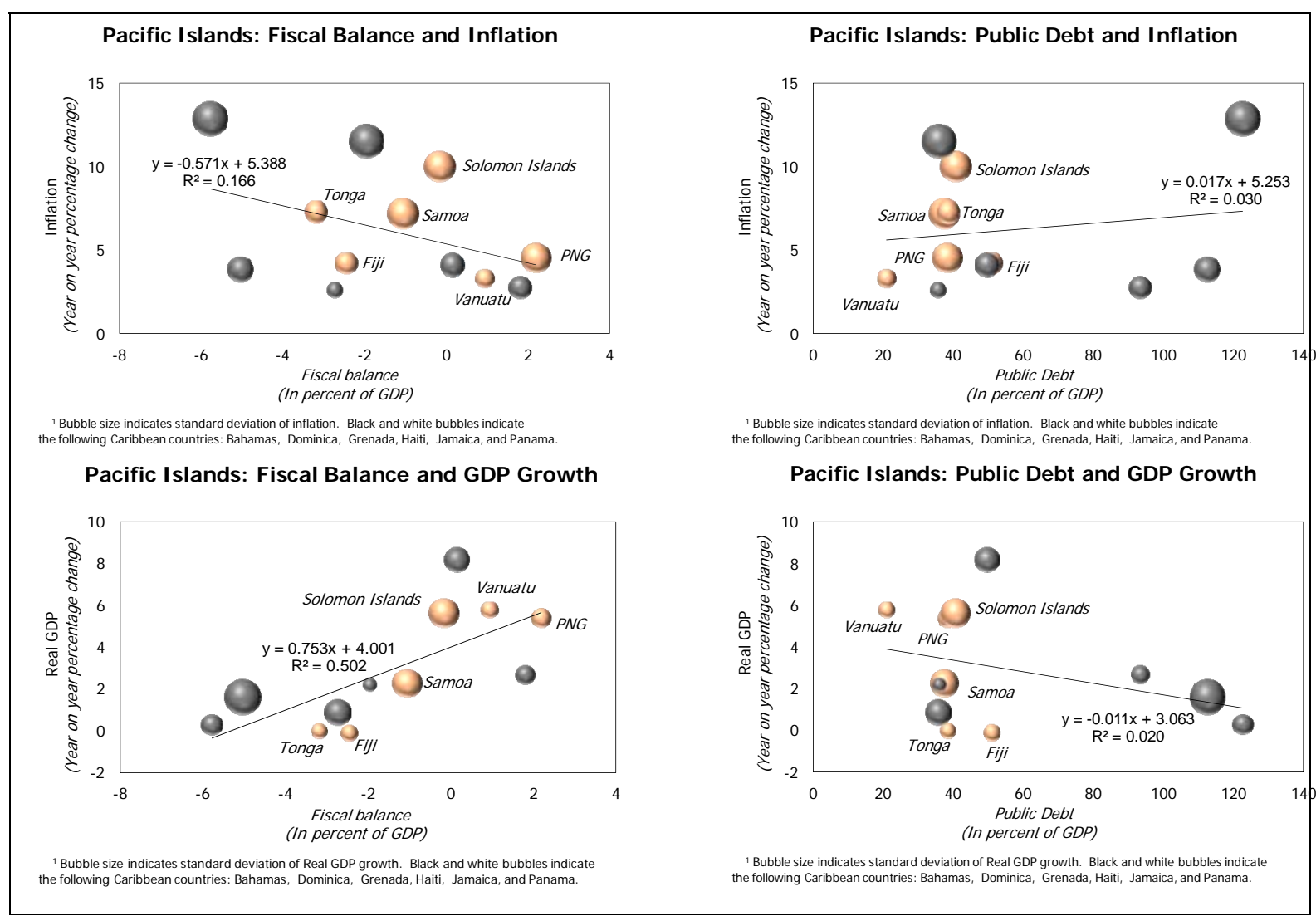

Source: IMF staff estimates.

\section{SUMMARY AND POLICY IMPLICATIONS}

The recent experience in managing the impact of the global financial crisis has highlighted the weakness of monetary policy transmission in PICs. In particular, interest rate passthrough — a channel to lower borrowing costs to boost economic activity-seems to be quite limited in some countries. On the other hand, the credit channel of monetary policy transmission appears to be stronger in some countries. However, the weak interest rate passthrough should not be interpreted as total ineffectiveness of monetary policy in influencing commercial interest rates, as other factors, such as changes in risk premia (including risk arising from policy interventions, such as controls and restrictions) and the availability of investment opportunities, could also offset the effects of monetary policy on commercial interest rates and credit growth.

Nevertheless, cross-country variations in pass-through point to the disconnect of policy rates from money markets in some countries. This is exacerbated by the inactive use of policy rates, weakening their signaling effects. It is thus not surprising, especially given the shallow money markets, that monetary policy transmission through the interest rate channel is relatively weak. During the recent crisis, monetary easing has not been supported by real exchange rate movements, because domestic inflation was higher than in trading partners and nominal exchange rate adjustments were avoided due to concerns about rapid inflation passthrough. This further diminished the power of monetary policy to stimulate economic activity. 
Continued efforts to develop domestic financial markets should be the key focus in strengthening monetary policy transmission. Measured by standard indicators, such as the ratio of broad money to GDP and the availability of financial products, domestic financial markets in PICs are relatively shallow compared with comparable countries such as those in the Caribbean. A deeper financial market would strengthen monetary policy transmission not only through interest rate and credit channels, but also through other channels that are likely to be very weak at present-such as those through asset prices and balance sheets that are effective only in deep and sophisticated financial markets.

Improving market infrastructure will be a critical step to strengthen monetary transmission. In many PICs, specific measures could include establishing credit reporting bureaus, secured transactions laws, and collateral registries. Moreover, the enforcement of credit contracts needs to be strengthened to ensure reliable and rapid resolution of defaults, bankruptcies and disputes. As market infrastructure improves, countries can accelerate the development of financial products, such as commercial paper, corporate bonds, equities, and foreign exchange products.

While focusing on the development of domestic financial markets as a long-term goal, policymakers need to expand the use of their toolkit in macroeconomic management. The ultimate objective of monetary policy—and those of other macroeconomic policies-is to achieve low and stable inflation and high economic growth. Achieving this objective, along with other intermediate objectives such as protecting foreign reserves, calls for use of all macroeconomic tools available and close coordination in the application of these tools, especially when monetary policy transmission is weak.

Exchange rate policy remains a powerful tool for macroeconomic stabilization in PICs. Fixed exchange rates have provided a useful nominal anchor, and this benefit should be recognized. However, some exchange rate flexibility (i.e., a band around a central rate) would help countries absorb the impact of external shocks that are frequent in PICs. Monetary and fiscal policy adjustment without the support of such exchange rate flexibility would require larger changes in domestic prices to restore external balance and could result in larger output losses. Such flexibility could be extended to one-off devaluations of the central parity when inconsistent fiscal and monetary policies have made the fixed exchange rate untenable at its set level. Of course, such considerations should be carefully examined at the country level for their feasibility and appropriateness.

Prudent fiscal policy is vital to macroeconomic stability in PICs. To maintain a credible fixed exchange rate, fiscal policy must ensure that government spending does not lead to higher inflation than in trade partners. Even when governments finance spending in a noninflationary manner, they would still need to be mindful of crowding-out private sector credit. Past experience in PICs and the Caribbean shows that prudent fiscal policy does pay off: lower fiscal deficits and lower public debt seem to be associated with lower average inflation and higher GDP growth. Moreover, lower fiscal deficits and lower public debt are also associated with lower variability of inflation. 


\section{References}

Australia and New Zealand Governments, 2010. “Trends in Remittance Fees and Charges”, paper prepared for the Forum Economic Ministers’ Meeting, Niue, 26-29 October.

Bank of England, 2010. “The Transmission Mechanism of Monetary Policy,” Bank of England, available at www.bankof England.co.uk.

Brook, Ray, 2007. "Inflation and Monetary Policy Reform" in Anoop Singh, Josh Felman, Ray Brooks, Tim Callen, and Christian Thimann (eds.) Australia: Benefiting from Economic Reform (Washington, International Monetary Fund).

Chami, Ralph, Barajas, Adolfo, Cosimano, Thomas F., Fullenkamp, Connel, Gapen, Michael T., Montiel, Peter, 2008. Macroeconomic Consequences of Remittances, Occasional Paper No. 259 (Washington: International Monetary Fund).

Cottarelli, C. and A. Kourelis. 1994. "Financial Structure, Bank Lending Rates, and the Transmission Mechanism of Monetary Policy.” IMF Staff Papers 41(4): 587-623.

Dabla-Norris, Era and Holger Floerkemeier, 2006. “Transmission Mechanisms of Monetary Policy in Armenia: Evidence from VAR Analysis,” IMF Working Paper WP/06/248 (Washington: International Monetary Fund).

Espinosa-Vega, Marco, and Alessandro Rebucci, 2003, "Retail Bank Interest Rate PassThrough: Is Chile Atypical?,” IMF Working Paper 03/112 (Washington: International Monetary Fund).

Guimarães-Filho, Roberto and Marta Ruiz-Arranz, 2009, Monetary Transmission in Asia: Is It Working? Regional Economic Outlook: Asia and the Pacific, October 2009 (Washington: International Monetary Fund.

International Monetary Fund, 2010. “Fiji: 2009 Article IV Consultation—Staff Report,” IMF Country Report, May (Washington: International Monetary Fund).

Jayaraman, T.K. and Dahalan, J., 2009. "Monetary Policy Transmission in An Undeveloped South Pacific Island Country: A Case Study of Samoa,” International Journal of Monetary Economics and Finance, 1(4): 380-398.

Jayaraman, T.K. and Chee-Keong Choong, 2009. "How Does Monetary Policy Transmission Work in Fiji?,” International Review of Economics, 56:145-61.

Kumar, Saten and Rup Singh, 2009. "Some Empirical Evidence on the Demand for Money in the Pacific Island Countries,” Auckland University of Technology, July.

Loayza, Norman and Klaus Schmidt-Hebbel, 2002. "Monetary Policy Functions and Transmission Mechanisms: An Overview," in Norman Loayza and Klaus Schmidt Hebbel (eds.), Monetary Policy: Rules and Transmission Mechanisms (Santiago: Central Bank of Chile). 
Moazzami, B., 1999. "Lending Rate Stickiness and Monetary Transmission Mechanism: The Case of Canada and the United States”, Applied Financial Economics, 9:533-38.

PFTAC, 2010. “Interest Rates and Bank Profitability in the South Pacific,” paper prepared for the Pacific Forum Economic Ministers’ Meeting, Niue, 26-29 October.

Pongsaparn, Runchana, 2010. “Samoa: Impediments to Bank Intermediation and Monetary Transmission,” Selected Issues Papers (Washington: International Monetary Fund).

Viñals, Jose and Jonathan Fletcher, 2010. 'The Making of Good Supervision: Learning to Say “No”,' IMF Staff Position Note, SPN 10/08, May 18 (Washington: International Monetary Fund).

Wood, Richard, 2010. “Monetary and Exchange Rate Policy Issues in Pacific Island Countries,” Treasury Working Paper, No. 2010-05, September. Canberra. 


\section{Appendix. Estimating Interest Rate and Credit Pass-Through}

We used an autoregressive distributed lags (ADL) model to estimate interest rate and credit pass-through. The model postulates the relationship between the policy rate and lending (deposit) rate as follows:

$l_{t}=\alpha_{0}+\alpha_{1 *} m_{t}+\alpha_{2^{*}} p_{\mathrm{t}}+\alpha_{3^{*}} l_{\mathrm{t}-1}+\alpha_{4^{*}} p_{\mathrm{t}-1}+\varepsilon_{\mathrm{t}}$.

Where $l_{t}=$ lending rate;

$$
\begin{aligned}
& m_{t}=\text { time trend } \\
& p t=\text { policy rate } \\
& \varepsilon_{\mathrm{t}}=\text { error term } \\
& \alpha=\text { parameters to be estimated }
\end{aligned}
$$

The long-run interest pass-through is measured by $\left(\alpha_{2}+\alpha_{4}\right) /\left(1-\alpha_{3}\right)$.

This type of Autoregressive Distributed Lags (ADL) models has been widely used in empirical studies to compare the interest rate pass-through across countries (Cottarelli and Kourelis, 1994; Moazzami, 1999; Espinosa-Vega and Rebucci, 2003; Guimarães and RuizArranz, 2009; and Pongsaparn, 2010). Another type of popular models for the analysis of monetary policy transmission is the Vector Autoregression (VAR) model. However, the multivariable-VAR approach requires much more information and determination of the optimal lag length for each variable. Moreover, a VAR model with long lag structures would reduce estimation efficiency in small samples. The two-variable ADL model used here can be re-parameterized as a VAR-type error-correction model (ECM) without altering the estimated residuals.

The ADL model for estimating credit pass-through follows a similar structure by essentially replacing the lending rate with credit growth in equation (1).

Data used for the estimation were compiled from various internal IMF sources, which are often supplied by country authorities. For easy reference, we have listed the sources below:

\section{Fiji}

Deposit rate (savings deposit rate): IMF, International Financial Statistics (IFS) database. Lending rate (maximum commercial bank lending rate): IMF, IFS database.

Policy rate (bank rate, end of period): IMF, IFS database.

Private sector credit (monthly): IMF, MBTS database.

Private sector credit (annual): IMF, APDLISC database.

Excess reserves: IMF staff estimates.

Loan to deposit ratio: IMF, MBTS database.

Overall fiscal balance: IMF, APDLISC database.

Total government debt: IMF, APDLISC database. 


\section{PNG}

Deposit rate: weighted average. Source: Country Authority.

Lending rate: weighted average. Source: Country Authority.

Policy rate: bank rate (end of period). Source: Country Authority.

Private sector credit (monthly): Source: Country Authority.

Private sector credit (annual): Source: IMF, APDLISC database.

Excess reserves: Source: Country Authority and IMF staff estimates.

Loan to deposit ratio: Source: Country Authority and IMF staff estimates.

Overall fiscal balance: Source: IMF, APDLISC database.

Total government debt: Source: IMF, APDLISC database.

\section{Samoa}

Deposit rate (weighted average): Central Bank of Samoa.

Lending rate (weighted average): Central Bank of Samoa.

Policy rate (bank rate, end of period): Central Bank of Samoa.

Private sector credit (monthly): Central Bank of Samoa.

Private sector credit (annual): IMF, APDLISC database.

Excess reserves: Central Bank of Samoa.

Loan to deposit ratio: Central Bank of Samoa.

Overall fiscal balance: IMF, APDLISC database.

Total government debt: IMF, APDLISC database.

\section{Solomon Islands}

Deposit rate: Central Bank of Solomon Islands (CBSI).

Lending rate: Central Bank of Solomon Islands (CBSI).

Private sector credit (monthly): Central Bank of Solomon Islands (CBSI).

Private sector credit (annual): IMF, APDLISC database.

Excess reserves: Central Bank of Solomon Islands (CBSI) and IMF staff estimates.

Loan to deposit ratio: Central Bank of Solomon Islands (CBSI) and IMF staff estimates.

Overall fiscal balance: IMF, APDLISC database.

Total government debt: IMF, APDLISC database.

\section{Tonga}

Deposit rate (6 months): National Reserve Bank of Tonga.

Lending rate (weighted average): National Reserve Bank of Tonga.

Private sector credit (monthly): National Reserve Bank of Tonga.

Private sector credit (annual): IMF, APDLISC database.

Excess reserves: National Reserve Bank of Tonga and IMF staff estimates.

Loan to deposit ratio: National Reserve Bank of Tonga and IMF staff estimates.

Overall fiscal balance: IMF, APDLISC database.

Total government debt: IMF, APDLISC database. 


\author{
Vanuatu \\ Deposit rate: three months (representative): IMF, IFS database. \\ Lending rate: commercial advances (representative): IMF, IFS database. \\ Policy rate: discount rate (end of period): IMF, IFS database. \\ Private sector credit (monthly): IMF, MBRF2 database. \\ Private sector credit (annual): IMF, APDLISC database. \\ Excess reserves: IMF, MBRF2 database. \\ Loan to deposit ratio: IMF, MBRF2 database. \\ Overall fiscal balance: IMF, APDLISC database. \\ Total government debt: IMF, APDLISC database.
}

